\title{
Myrtaceae throughout the Espinhaço Mountain Range of central- eastern Brazil: floristic relationships and geoclimatic controls
}

\author{
Mariana de Oliveira Bünger ${ }^{1,2}$, João Renato Stehmann ${ }^{1}$ and Ary Teixeira Oliveira-Filho
}

Received: 6 March, 2013. Accepted: 28 November, 2013

\begin{abstract}
Although biological surveys and taxonomic revisions provide key information to ecological and evolutionary studies, there is a clear lack of floristic and phytogeographic studies of the mountainous regions of Brazil, which harbor some of the most threatened plant ecosystems on the planet. Myrtaceae has been reported to be one of the most important families in the upland areas of Brazil, as well as in the Atlantic Forest Domain. In this study, we investigated the floristic composition of Myrtaceae throughout the Espinhaço Mountain Range and adjacent highlands of central-eastern Brazil, testing the following hypotheses: floristic similarity increases with geographic proximity; and species distribution is affected by geoclimatic variables. We performed statistical analyses using a database containing records of 199 species in 19 areas and of their respective geoclimatic variables. We also performed ordination analysis using non-metric multidimensional scaling (NMDS), the first and second axes of which explained $69 \%$ and $78 \%$ of the variation, respectively. The NMDS analysis demonstrated that variations in the Myrtaceae flora are highly sensitive to geoclimatic variables and geographic proximity. The NMDS ordination also showed a predominantly south-north gradient, as did the cluster analysis. This gradient was highly correlated with variations in rainfall and temperature, which are also associated with the three domains that coincide with the Espinhaço Mountain Range.
\end{abstract}

Key words: floristic connections, montane regions, multivariate analysis, Atlantic Forest

\section{Introduction}

Biological surveys and taxonomic revisions provide key information to ecological and evolutionary studies. Greater knowledge of floristic variations has furthered the understanding of phytogeographic patterns and the spatial organization of plant communities (Gentry 1982; Prance 1982; Safford 2007). Biogeographic hypotheses involving plant species composition, for instance, often result from previous surveys (Clarke \& Funk 2005; Funk 2006). Nevertheless, most phytogeographic studies conducted in Brazil have been published as sections of phylogenetic studies or floristic descriptions of small areas or of entire domains (Fiaschi \& Pirani 2009).

There is a clear lack of floristic and phytogeographic studies of the mountain ranges of Brazil, which harbor plant ecosystems that are some of the most threatened on the planet (Webster 1995; Martinelli 2007), even more so than are those of the Andes (Safford 1999). The Espinhaço Mountain Range, in central-eastern Brazil, is the second largest mountain range in the country, in terms of its length (ca. $1200 \mathrm{~km}$ ), its northern and southern extremities being in the municipalities of Jacobina, in the state of Bahia (ca. $11^{\circ} 20^{\prime} \mathrm{S}$ ), and Ouro Branco, in the state of Minas Gerais (ca. 20 $20^{\circ}$ 's), respectively (Giulietti et al. 1997; Harley et al. 1995). Elevations range from $900 \mathrm{~m}$ to $2000 \mathrm{~m}$, and landforms include hilly lands, tablelands, steep crests and deep river valleys. The Espinhaços are known as a major center of plant diversity and endemism (Giulietti et al. 1997). The predominant vegetation type is campo rupestre (rocky grassland/savanna, sensu Oliveira-Filho 2009), although the vegetation mosaic also includes forest and dwarf forest. The floristic composition of the range is strongly affected by the three domains it crosses (Giulietti et al. 1997), hereafter referred to as the Southern, Central and Northern Espinhaço. The Southern Espinhaço, in central Minas Gerais, is within the Atlantic Forest Domain; the Central Espinhaço, also in Minas Gerais, lies within the Cerrado (Savanna) Domain (sensu Batalha 2011); and the Northern Espinhaço, in Bahia, which is entirely within the Caatinga (Shrublands) Domain (Harley et al. 1995), is more often referred to as separate mountain range, the Chapada Diamantina, than as a section of the Espinhaços. In fact, there is a gap between the central and northern portion that adds to the relative isolation of the Northern Espinhaço.

\footnotetext{
${ }^{1}$ Universidade Federal de Minas Gerais, Instituto de Ciências Biológicas, Departamento de Botânica, Laboratório de Sistemática Vegetal, Belo Horizonte, MG, Brazil

${ }^{2}$ Author for correspondence: maribunger@gmail.com
} 
Myrtaceae has been reported to be one of the most important families in the Espinhaço Mountain Range, occurring mainly in gallery forests and areas of campo rupestre (Giulietti et al. 1997). Within the Central Espinhaço, Kawasaki (1989) reported 11 genera and 46 species for the Serra do Cipó; Hatschbach et al. (2006) reported six genera and 21 species for the Serra do Cabral; and Kawasaki (2004) reported nine genera and 34 species for the Serra de Grão Mogol. In the Northern Espinhaço, Nic Lughadha (1995) reported nine genera and 30 species for the Pico das Almas. Other studies have emphasized the importance of Myrtaceae has also been demonstrated in studies of the floristic composition of other highlands within Minas Gerais, such as the regions known as the "Quadrilátero Ferrífero" (Iron Quadrangle) and "Triângulo Mineiro" (Minas Triangle), as well as the Serra da Mantiqueira Mountain Range (Morais \& Lombardi 2006; Viana \& Lombardi 2007; Alves \& Kolbec 2009). Geology, climate and topography are believed to be the leading factors determining the difference in floristic composition between the Espinhaços and the neighboring highlands (Giulietti et al. 1997). Patterns of species distribution across these highlands may also reflect climatic changes during the Pleistocene, including the coalescence and isolation of plant populations (Gentry 1995). Studies that relate floristic and environmental aspects in the Espinhaços are therefore of great value in clarifying these issues (Giulietti \& Pirani 1988).

In the present contribution, we investigated the floristic composition of Myrtaceae throughout the Espinhaços and in adjacent upland areas. Our aim was to test the following hypotheses: floristic similarity increases with geographic proximity; and species distribution is affected by geoclimatic variables.

\section{Material and methods}

\section{The dataset}

We created a database containing metadata on Myrtaceae checklists for the Espinhaço Mountain Range and neighboring highlands, obtained from the literature and from specimens in the collections of the following herbaria (acronyms follow Thiers 2010): the Herbarium of the Federal University of Minas Gerais (acronym, BHCB); the Herbarium of the Federal University of Ouro Preto (acronym, OUPR); and the Herbarium of the Research Institute of the Rio de Janeiro Botanical Garden (acronym, RB). We discarded studies with a high number of indeterminate taxa and did not consider infraspecific categories. We standardized the names by exclusion of nomenclatural synonyms, following Govaerts et al. (2007) and Sobral et al. (2010). The number of species in some areas therefore differs from that reported in the original literature. We evaluated a total of 19 areas, all at elevations above $700 \mathrm{~m}$ a.s.l. (Fig. 1, Tab. 1). We also used the studies of Sano et al. (2008) and Stehmann et al. (2009) to assess the species endemism in the Cerrado and Atlantic Forest Domains, respectively.

\section{Cluster analysis}

We performed a hierarchical classification of floristic areas by applying the unweighted pair group method with arithmetic mean algorithm, with Sørensen coefficients of similarity among areas, using the PAleontological STatistics program (Hammer et al. 2001). The Sørensen similarity coefficient has been recommended for studies of species-rich communities because it assigns a higher weight to common occurrences (Valentin 2000; Mueller-Dombois \& Ellenberg 1974). Because analyses including and excluding singletons produced very similar cluster topologies, we decided to include them in the original matrix, as recommended by Mueller-Dombois \& Ellenberg (1974) for communities with high numbers of unique species.

We performed a Mantel test (Sokal \& Rohlf 1995), using the PC-ORD software package, version 5.0 (McCune \& Mefford 2006), together with a Monte Carlo test, involving 5000 permutations, to compare the matrices of geographic distances and floristic similarities.

\section{Spatial analyses}

In order to reduce the dimensionality of the species matrix into ordination axes, we made a number of trials with three ordination techniques available in PC-ORD (McCune \& Mefford 2006) and their algorithmic options. We also tried different cut-off levels to eliminate outlying areas. In the end, we chose the set of options that produced the best result in terms of interpretive power of the species composition patterns (Kent \& Coker 1992).

The three ordination techniques were correspondence analysis, also known as reciprocal averaging (Hill 1973); non-metric multidimensional scaling (NMDS) ordination analysis, as described by McCune \& Grace (2002), with the quantitative version of Sørensen's distance measure; and detrended correspondence analysis (Hill \& Gauch 1980). The correspondence analysis was discarded because it showed a very strong compression effect (Gauch 1982). The other two techniques showed no compression and produced similar ordination patterns. We eventually chose NMDS because it is not optimized to depict the most important intrinsic gradients in the data (as does detrended correspondence analysis) but to produce a low-dimensional solution to display the inter-sample (interspecific) relationships. The significance of ordination axes was assesses by Monte Carlo tests applied to the stress in real and randomized data.

We used the software SAM, version 4.0 (Rangel et al. 2010 ) to produce correlograms for each main NMDS axis, plotting Moran's I across distance classes in order to assess the spatial structure of each set of ordination scores (Legendre \& Fortin 1989; Diniz-Filho et al. 2003). We adopted 


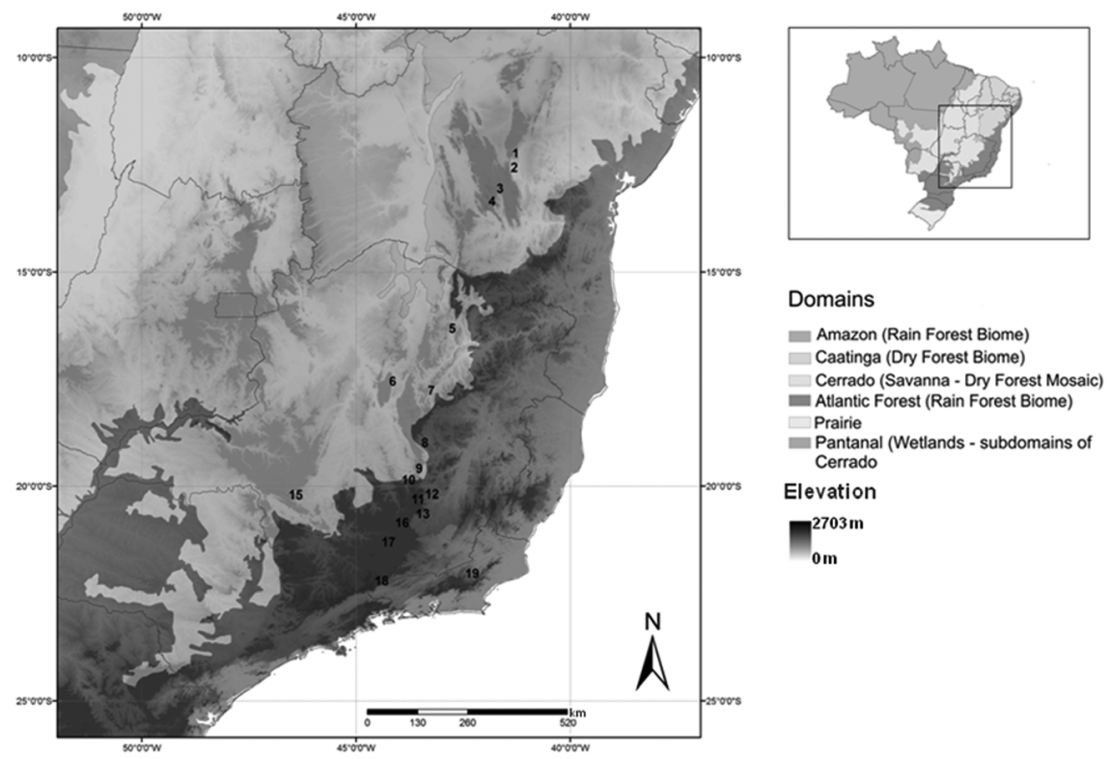

Figure 1. Distribution of Myrtaceae species throughout the Espinhaço Mountain Range and adjacent highlands of the 19 upland areas for which floristic surveys were available, located in the states of Bahia (BA), Minas Gerais (MG), and Rio de Janeiro (RJ): 1-Morro da Chapadinha, Lençóis, BA; 2-Morro do Pai Inácio, Palmeiras, BA; 3-Catolés, BA; 4-Pico das Almas, BA; 5-Grão Mogol, MG; 6-Serra do Cabral, MG; 7-Rio Preto State Park, MG; 8-Serra do Cipó National Park, MG; 9-Serra da Piedade, MG; 10-Serra da Calçada, MG; 11-Serra do Caraça, MG; 12-Itacolomi State Park, MG; 13-Ouro Branco, MG; 14-Serra da Canastra, MG; 15-Delfinópolis, MG; 16-Serra de São José, MG; 17-Ibitipoca State Park, MG; 18-Itatiaia, RJ; and 19-Macaé de Cima, RJ.

Table 1. Summary of the 19 upland areas studied in central-eastern Brazil.

\begin{tabular}{|c|c|c|c|c|c|c|}
\hline \multirow[b]{2}{*}{ Area, location } & \multirow[b]{2}{*}{ Latitude } & \multirow[b]{2}{*}{ Longitude } & \multirow{2}{*}{$\begin{array}{l}\text { Elevation } \\
\text { (m a.s.l.) }\end{array}$} & \multicolumn{2}{|c|}{ Myrtaceae } & \multirow[b]{2}{*}{ Reference } \\
\hline & & & & $\begin{array}{c}\text { Genera } \\
(\mathrm{n})\end{array}$ & $\begin{array}{c}\text { Species } \\
(\mathrm{n})\end{array}$ & \\
\hline Morro do Pai Inácio, Palmeiras, BA & $12^{\circ} 27^{\prime} \mathrm{S}$ & $41^{\circ} 27^{\prime} \mathrm{W}$ & 715 & 5 & 17 & Barroso \& Funch (1988) \\
\hline Morro da Chapadinha, Lençóis, BA & $12^{\circ} 28^{\prime} \mathrm{S}$ & $41^{\circ} 25^{\prime} \mathrm{W}$ & 715 & 7 & 19 & Barroso \& Funch (1988) \\
\hline Pico das Almas, BA & $13^{\circ} 43^{\prime} \mathrm{S}$ & $41^{\circ} 57^{\prime} \mathrm{W}$ & 877 & 8 & 24 & Nic Lughadha (1995) \\
\hline Catolés, BA & $13^{\circ} 27^{\prime} \mathrm{S}$ & $41^{\circ} 57^{\prime} \mathrm{W}$ & 1041 & 10 & 35 & Zappi et al. (2003) \\
\hline Grão Mogol, MG & $16^{\circ} 35^{\prime} \mathrm{S}$ & $42^{\circ} 54^{\prime} \mathrm{W}$ & 819 & 7 & 27 & Kawasaki (2004) \\
\hline Serra do Cabral, MG & $17^{\circ} 47^{\prime} \mathrm{S}$ & $44^{\circ} 17^{\prime} \mathrm{W}$ & 1088 & 5 & 19 & Hatschbach et al. (2006) \\
\hline Rio Preto State Park, MG & $18^{\circ} 00^{\prime} \mathrm{S}$ & $43^{\circ} 23^{\prime} \mathrm{W}$ & 887 & 9 & 37 & Viana (unpublished) \\
\hline Serra do Cipó National Park, MG & $19^{\circ} 13^{\prime} \mathrm{S}$ & $43^{\circ} 32^{\prime} \mathrm{W}$ & 1170 & 11 & 45 & Kawasaki (1989) \\
\hline Serra de Ouro Branco, MG & $20^{\circ} 29^{\prime} \mathrm{S}$ & $43^{\circ} 40^{\prime} \mathrm{W}$ & 1109 & 10 & 23 & Santos (unpublished) \\
\hline Serra do Caraça, MG & $20^{\circ} 05^{\prime} \mathrm{S}$ & $43^{\circ} 29^{\prime} \mathrm{W}$ & 953 & 11 & 49 & Morais \& Lombardi 2006 \\
\hline Itacolomi State Park, MG & $20^{\circ} 25^{\prime} \mathrm{S}$ & $43^{\circ} 27^{\prime} \mathrm{W}$ & 921 & 11 & 45 & Bünger et al. (unpublished) \\
\hline Serra da Canastra, MG & $20^{\circ} 15^{\prime} \mathrm{S}$ & $46^{\circ} 30^{\prime} \mathrm{W}$ & 1021 & 8 & 35 & Romero et al. (unpublished) \\
\hline Delfinópolis, MG & $20^{\circ} 26^{\prime} \mathrm{S}$ & $46^{\circ} 38^{\prime} \mathrm{W}$ & 1091 & 7 & 18 & Romero et al. (unpublished) \\
\hline Serra da Calçada, MG & $20^{\circ} 05^{\prime} \mathrm{S}$ & $43^{\circ} 59^{\prime} \mathrm{W}$ & 1133 & 8 & 19 & Viana \& Lombardi (2007) \\
\hline Serra de São José, MG & $21^{\circ} 05^{\prime} \mathrm{S}$ & $44^{\circ} 09^{\prime} \mathrm{W}$ & 1001 & 8 & 17 & Alves \& Kolbec (2009) \\
\hline Ibitipoca State Park, MG & $21^{\circ} 32^{\prime} \mathrm{S}$ & $43^{\circ} 88^{\prime} \mathrm{W}$ & 979 & 11 & 35 & RB database \\
\hline Serra da Piedade, MG & $19^{\circ} 49^{\prime} \mathrm{S}$ & $43^{\circ} 40^{\prime} \mathrm{W}$ & 851 & 7 & 17 & BHCB database \\
\hline Serra do Itatiaia, RJ & $22^{\circ} 50^{\prime} \mathrm{S}$ & $44^{\circ} 58^{\prime} \mathrm{W}$ & 985 & 13 & 69 & RB database \\
\hline Macaé de Cima, RJ & $22^{\circ} 16^{\prime} \mathrm{S}$ & $42^{\circ} 31^{\prime} \mathrm{W}$ & 1078 & 11 & 42 & Barroso \& Peron (1994) \\
\hline
\end{tabular}

BA - (state of) Bahia; MG - (state of) Minas Gerais; RJ - (state of) Rio de Janeiro; RB - Herbarium of the Research Institute of the Rio de Janeiro Botanical Garden; $\mathrm{BHCB}$ - Herbarium of the Federal University of Minas Gerais. 
a significance level of 0.05 in all statistical tests and 1000 permutations in all randomizations, and we followed Zar (2009) for inferential tests.

In order to investigate the relationship among the species composition patterns summarized by the main NMDS axes (ordination scores as response variables) and the set of predictor geoclimatic variables, we performed a number of procedures. Those procedures are described below.

The matrix containing the geoclimatic variables was composed of the median elevation of each area and the 19 bioclimatic parameters yielded by WorldClim, version 1.4 (Hijmans et al. 2005). We first checked the set of variables for multicollinearity, calculating their variance inflation factor and adopting a cut-off value of 10 (Henderson \& Seaby 2007), which indicated high levels of multicollinearity. The geoclimatic variables maintained were the same for axes 1 and 2 of the NMDS ordination analysis: annual precipitation; isothermality; and total precipitation for the driest quarter. All these models were free of multicollinearity.

We assessed the goodness of fit of the models through the adjusted coefficient of determination $\left(R_{\text {adj }}^{2}\right)$ and significance ( $p$ value), examining the residuals graphically to check them for the linearity assumption. We also tested the residuals for normality using Shapiro-Wilk tests (Zar 2009), and they failed to meet that assumption for axis 2 only. We obtained normality for this axis after transforming the variables using the natural log. We then assessed the significance of each predictor variable on the NMDS scores by calculating the total and partial $R^{2}$ values and the values of $p$.

As the lack of spatial independence can inflate the risk of a type I error in statistical tests (Legendre \& Fortin 1989), we tested the residuals for spatial structure (Diniz-Filho et al. 2003) of all generalized linear models (GLMs) through correlograms produced with Moran's I, as described above. For axis 2 , in particular, we then tested the global significance of spatial autocorrelations of the correlograms on the basis of the sequential Bonferroni correction, as recommended by Fortin \& Dale (2005). The number and size of distance classes followed the default in the SAM program. All the residuals for axes 1 and 2 were eventually free of spatial autocorrelation.

\section{Results}

\section{Similarity among the areas}

We reported 199 species and 15 genera in the dataset. The richest genera, collectively accounting for $68 \%$ of the total Myrtaceae flora and recorded in all areas, were Myrcia (67 species), Eugenia (62 species) and Psidium (20 species). The genera Algrizea, Neomitranthes and Pimenta, with one species each, were restricted to individual areas. Algrizea macrochlamys, endemic to the Chapada Diamantina Mountain Range, was registered only in the Catolés area.
Neomitranthes glomerata was restricted to the Macae de Cima Ecological Reserve, and Pimenta pseudocaryophyllus was restricted to the Ibitipoca State Park, Itatiaia National Park and Macaé de Cima Ecological Reserve. Species of Myrceugenia and Siphoneugena were restricted to areas with higher elevation and humidity, i.e., those located in the Quadrilátero Ferrífero and Serra da Mantiqueira regions.

Most of the areas studied contained between 20 and 40 Myrtaceae species. We registered 46 and 49 species in the Itacolomi and Serra do Caraça areas, respectively, and a remarkable richness of 70 species in the Serra do Itatiaia area. We considered species to have a wide distribution if they occurred in 11 or more areas, and only 11 species (5\%) met this criterion. In great contrast, $54 \%$ of the species identified occurred in a single area, indicating low floristic similarity among the areas. This was also evidenced by the fact that the similarity indices were low $(<0.50)$ for the comparisons between most of the areas (Tab. 2). The similarity index was highest (0.57) for the comparison between the Catolés and Pico das Almas areas, both in the Chapada Diamantina Mountain Range, followed by 0.55 for that between the Itacolomi and Serra do Caraça areas, both in the southern extreme of the Espinhaço Mountain Range, in central Minas Gerais.

Cluster analyses of the similarity indices (Fig. 2) identified some clear patterns related to the geographic distribution of the species, as follows:

Group I-an outlier, encompassing two southern areas, both in the state of Rio de Janeiro and surrounded by Atlantic Forest: Itatiaia and Macaé de Cima

Group II-comprising the Pai Inácio and Chapadinha areas of the Northern Espinhaço, within the semi-arid Caatinga Domain

Group III-including the Serra da Piedade, Ibitipoca and Serra do Cipó areas, together with three areas within the Quadrilátero Ferrífero region (Serra do Caraça, Ouro Branco and Itacolomi), all of which share borders with areas of semideciduous Atlantic Forest as well as with patches of cerrado

Group IV-the most complex group, comprising a major subgroup consisting of three areas in the Central Espinhaço (Grão Mogol, Serra do Rio Preto, Serra do Cabral) and two in the western highlands of the Triangulo Mineiro region (Canastra and Delfinópolis), all five areas being within the Cerrado Domain, as well as two minor and rather distinct subgroups, including, respectively, two southern areas within the Cerrado Domain but also bordering areas of semideciduous Atlantic Forest (the Serra da Calçada and Serra de São José areas) and two outliers of the Northern Espinhaço, within the Caatinga Domain (the Catolés and Pico das Almas areas)

\section{Explanatory spatial and environmental variables underlying variations in species composition}

Monte Carlo tests applied to the stress in randomized data indicated that the first two NMDS axes were both significant 
Table 2. Matrix of the Sørensen similarity coefficients among the 19 upland areas studied in central-eastern Brazil.

\begin{tabular}{|c|c|c|c|c|c|c|c|c|c|c|c|c|c|c|c|c|c|c|c|}
\hline Area & BApalm & BApai & BAcha & BAcat & MGgrao & $\begin{array}{l}\text { MGca- } \\
\text { bral }\end{array}$ & $\begin{array}{l}\text { MG- } \\
\text { preto }\end{array}$ & MGcipo & $\begin{array}{l}\text { MG- } \\
\text { branco }\end{array}$ & $\begin{array}{c}\text { MGca- } \\
\text { raca }\end{array}$ & MGita & MGcanal & MGdelfi & $\begin{array}{l}\text { MG- } \\
\text { calca }\end{array}$ & MGjose & MGibiti & $\begin{array}{l}\text { MG- } \\
\text { pieda }\end{array}$ & RJitati & RJcima \\
\hline BApalm & 1.00 & & & & & & & & & & & & & & & & & & \\
\hline BApai & 0.34 & 1.00 & & & & & & & & & & & & & & & & & \\
\hline BAcha & 0.23 & 0.50 & 1.00 & & & & & & & & & & & & & & & & \\
\hline BAcat & 0.58 & 0.31 & 0.37 & 1.00 & & & & & & & & & & & & & & & \\
\hline MGgrao & 0.35 & 0.27 & 0.22 & 0.32 & 1.00 & & & & & & & & & & & & & & \\
\hline MGcabral & 0.42 & 0.22 & 0.26 & 0.33 & 0.48 & 1.00 & & & & & & & & & & & & & \\
\hline MGpreto & 0.43 & 0.26 & 0.21 & 0.42 & 0.50 & 0.50 & 1.00 & & & & & & & & & & & & \\
\hline MGcipo & 0.32 & 0.16 & 0.16 & 0.28 & 0.33 & 0.34 & 0.39 & 1.00 & & & & & & & & & & & \\
\hline MGbranco & 0.34 & 0.20 & 0.14 & 0.28 & 0.40 & 0.38 & 0.50 & 0.47 & 1.00 & & & & & & & & & & \\
\hline MGcaraca & 0.25 & 0.15 & 0.18 & 0.31 & 0.34 & 0.29 & 0.51 & 0.45 & 0.44 & 1.00 & & & & & & & & & \\
\hline MGita & 0.34 & 0.17 & 0.17 & 0.29 & 0.26 & 0.30 & 0.41 & 0.44 & 0.53 & 0.56 & 1.00 & & & & & & & & \\
\hline MGcana & 0.37 & 0.23 & 0.19 & 0.34 & 0.39 & 0.44 & 0.50 & 0.43 & 0.41 & 0.36 & 0.37 & 1.00 & & & & & & & \\
\hline MGdelfi & 0.43 & 0.17 & 0.22 & 0.34 & 0.36 & 0.43 & 0.33 & 0.41 & 0.39 & 0.27 & 0.34 & 0.49 & 1.00 & & & & & & \\
\hline MGcalca & 0.33 & 0.22 & 0.11 & 0.22 & 0.30 & 0.42 & 0.43 & 0.38 & 0.38 & 0.26 & 0.33 & 0.44 & 0.27 & 1.00 & & & & & \\
\hline MGjose & 0.30 & 0.18 & 0.17 & 0.27 & 0.23 & 0.40 & 0.38 & 0.26 & 0.31 & 0.18 & 0.21 & 0.39 & 0.35 & 0.34 & 1.00 & & & & \\
\hline MGibiti & 0.14 & 0.16 & 0.19 & 0.17 & 0.16 & 0.23 & 0.25 & 0.30 & 0.46 & 0.36 & 0.51 & 0.29 & 0.23 & 0.30 & 0.24 & 1.00 & & & \\
\hline MGpieda & 0.24 & 0.12 & 0.11 & 0.15 & 0.18 & 0.22 & 0.30 & 0.29 & 0.30 & 0.33 & 0.34 & 0.31 & 0.34 & 0.28 & 0.18 & 0.31 & 1.00 & & \\
\hline RJitati & 0.15 & 0.08 & 0.10 & 0.24 & 0.13 & 0.12 & 0.15 & 0.17 & 0.13 & 0.26 & 0.28 & 0.12 & 0.12 & 0.04 & 0.06 & 0.24 & 0.10 & 1.00 & \\
\hline RJcima & 0.12 & 0.10 & 0.13 & 0.18 & 0.12 & 0.13 & 0.18 & 0.09 & 0.09 & 0.18 & 0.17 & 0.16 & 0.13 & 0.07 & 0.07 & 0.24 & 0.07 & 0.21 & 1.00 \\
\hline
\end{tabular}

BA - (state of) Bahia; MG - (state of) Minas Gerais; RJ - (state of) Rio de Janeiro; BApalm - Pico das Almas; BApai - Pai Inácio; BAcha - Chapadinha; BAcat - Catolés; MGgrao - Grão Mogol; MGcabral - Serra do Cabral; MGpreto - Serra do Rio Preto; MGcipo - Serra do Cipó; MGbranco - Ouro Branco; MGcaraca Serra do Caraça; MGita - Itacolomi; MGcana - Canastra; MGdelfi - Delfinópolis; MGcalca - Serra da Calçada; MGjose - Serra de São José; MGibiti - Ibitipoca; MGpieda - Serra da Piedade; RJitati - Itatiaia; RJcima - Macaé de Cima.

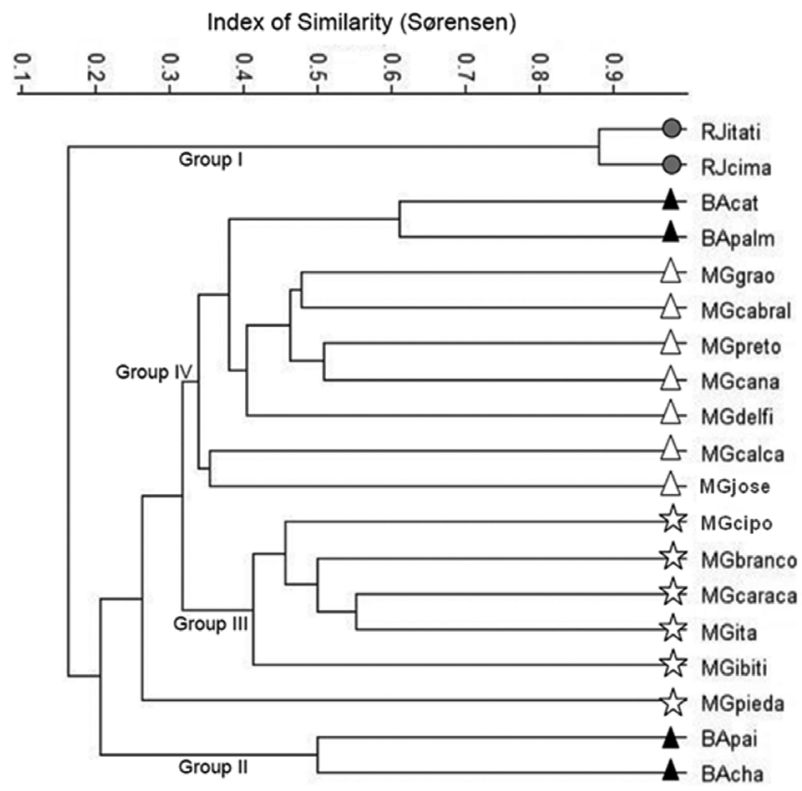

Figure 2. Dendrogram summarizing similarity patterns of the Myrtaceae flora among 19 upland areas of caatinga in central-eastern Brazil, in the states of Rio de Janeiro (RJ), Bahia (BA) and Minas Gerais (MG): Group I-Itatiaia (RJitati) and Macaé de Cima (RJcima); Group II-Pai Inácio (BApai) and Chapadinha (BAcha); Group III-Serra da Piedade (MGpieda), Ibitipoca (MGibiti), Serra do Cipó (MGcipo), Serra do Caraça (MGcaraca), Ouro Branco (MGbranco) and Itacolomi (MGita); and Group IV-including a major subgroup, comprising Grão Mogol (MGgrao), Serra do Rio Preto (MGpreto), Serra do Cabral (MGcabral), Canastra (MGcana) and Delfinópolis (MGdelfi), a first minor subgroup, comprising Serra da Calçada (MGcalca) and Serra de São José (MGjose), and a second minor subgroup, comprising Catolés (BAcat) and Pico das Almas (BApalm). Similarity patterns were obtained by clustering the Sørensen similarity coefficients and using the unweighted pair group method with arithmetic mean algorithm.

Cophenetic correlation coefficient $=0.8399$.

$\boldsymbol{\Delta}$ = caatinga (shrublands); $\Delta=$ cerrado (savanna); $i \vec{s}=$ semideciduous forest;

- rain forest.
(Tab. 3). In the ordination diagram yielded by NMDS (Fig. 3) most of the groups defined by the cluster analysis were segregated into distinct sectors, although with more clarity. Axis 1 was quite effective in depicting the north-south gradient, whereas axis 2 was very effective in segregating the two drought-free areas (areas of Atlantic Forest).

Two GLMs were produced for the species composition patterns summarized by the area scores on NMDS axes 1 and 2. Those GLMs are given in Tab. 4 together with the selected predictor variables, are shown in Tab. 4. All models produced strong correlations $\left(0.9>R_{\text {adj }}^{2}>0.7\right)$ and highly significant results $(p<0.01)$. The predictors that made the greatest contribution to the models produced for axes 1 and 2 were annual precipitation, isothermality and total precipitation during the driest quarter. For axis 1, those variables explained $69 \%$ of the variation in species composition among the 19 upland areas $\left(R_{\text {adj }}^{2}=0.694\right)$, compared with $78 \%\left(R_{\text {adj }}^{2}=0.7802\right)$ for axis 2 .

The Mantel test showed a negative correlation between floristic similarity and geographic distance $(p=0.009$, $R=-0.3452$ ). However, the GLMs showed no spatial structure in the residuals. Therefore no spatial filter was necessary.

\section{Discussion}

Tropical vegetation formations, especially those in Brazil, are known for their high species richness, including a considerable proportion of geographically restricted species (Gentry 1995). Among the main Brazilian vegetation types, Atlantic Forest and cerrado are remarkable for their high species richness and number of endemic species. Stehmann 
Table 3. Summary of the non-metric multidimensional scaling ordination analysis and the respective permutation tests performed for binary occurrence records for 199 species of Myrtaceae in 19 upland areas in central-eastern Brazil.

\begin{tabular}{|c|c|c|c|c|c|c|c|}
\hline \multirow[t]{2}{*}{ Axis } & \multicolumn{3}{|c|}{ Stress in real data 50 runs } & \multicolumn{4}{|c|}{$\begin{array}{l}\text { Stress in randomized data } \\
\text { Monte Carlo test, } 249 \text { runs }\end{array}$} \\
\hline & Minimum & Mean & Maximum & Minimum & Mean & Maximum & $p^{*}$ \\
\hline 1 & 28.848 & 43.031 & 54.462 & 33.340 & 48.797 & 54.613 & 0.0040 \\
\hline 2 & 13.813 & 16.965 & 36.625 & 20.898 & 26.193 & 31.901 & 0.0040 \\
\hline
\end{tabular}

${ }^{*} p=$ proportion of randomized runs with stress $\leq$ observed stress.

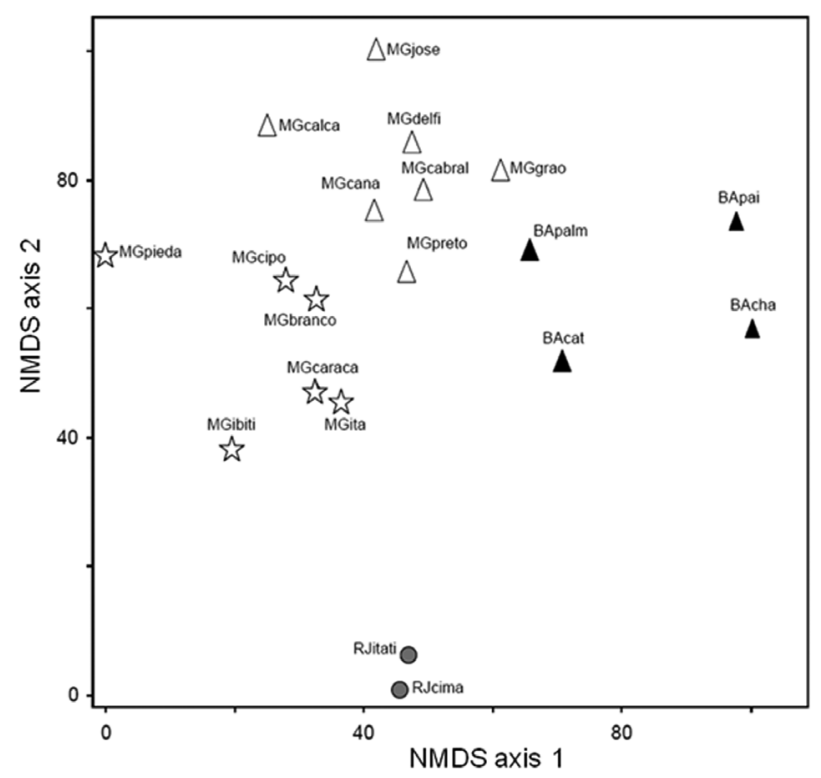

Figure 3. Ordination diagram yielded by non-metric multidimensional scaling (NMDS) ordination analysis of binary occurrence records for 199 species of Myrtaceae in 19 upland areas in central-eastern Brazil, in the states of Rio de Janeiro (RJ), Bahia (BA) and Minas Gerais (MG): Itatiaia (RJitati); Macaé de Cima (RJcima); Pai Inácio (BApai); Chapadinha (BAcha); Serra da Piedade (MGpieda); Ibitipoca (MGibiti); Serra do Cipó (MGcipo); Serra do Caraça (MGcaraca); Ouro Branco (MGbranco); Itacolomi (MGita); Grão Mogol (MGgrao); Serra do Rio Preto (MGpreto); Serra do Cabral (MGcabral); Canastra (MGcana); Delfinópolis (MGdelfi); Serra da Calçada (MGcalca); Serra de São José (MGjose); Catolés (BAcat); and Pico das Almas (BApalm). The diagram shows the ordination of the areas on the first two axes.

$\mathbf{\Delta}$ = caatinga (shrublands); $\Delta$ = cerrado (savanna); $\succsim$ = semideciduous forest; $\boldsymbol{\bullet}=$ rain forest.

et al. (2009) listed 15,782 species for the Atlantic Forest Domain, of which 7155 (45\%) are endemic to the domain. Sano et al. (2008) produced a list of 12,356 species for the Cerrado Domain, and Ratter et al. (2003) highlighted the high endemism of its flora. On the basis of the floristic checklists used in this study, we can state that Myrtaceae shows a similar pattern in the upland areas of central-eastern Brazil. Of the 199 species in the database employed, 122 (61\%) were found to occur in one or two locations, only 11 (5\%) occurring in more than 11 of the 19 areas analyzed and therefore considered to have a widespread distribution. These patterns are probably related not only to the contrasting contribution that the three distinct domains make to the savannas and forests of these highlands but also to the peculiar flora of the extensive areas of campo rupestre.

According to Semir (1991), the peculiar ecological condition of tropical rocky highland vegetation and its history of long periods of isolation are favorable to increased rates of speciation, a fact supported by the high degree of endemism found worldwide in this vegetation formation. The typical campo rupestre vegetation has a large number of species with unique morphological and physiological adaptations to the extreme conditions of soil and climate, such as high solar radiation, wide daily temperature range, strong persistent winds and stress caused excessive or insufficient ground water content (Giulietti et al. 1997; Benites 2001). Myrtaceae species are no exception, because they are also susceptible to these selective pressures, and the family is among the richest campo rupestre families (Giulietti \& Pirani 1988).

Among the genera of Myrtaceae, some are specific to one area of occurrence. For example, the monotypic genus Algrizea (represented by Algrizea macrochlamys), which was recently described as endemic to the Chapada Diamantina Mountain Range (Proença et al. 2006), is known only for the Catolés area, in Bahia. Although the genera Neomitranthes and Pimenta are found throughout the Atlantic Forest Domain in general (Landrum 1986; Souza 2009), Oliveira-Filho \& Fontes (2000) identified Pimenta pseudocaryophyllus as an indicator of upper montane semideciduous and rain forests. Neomitranthes, composed of 14 species and endemic to the Atlantic Forest Domain, was represented by a single species, N. glomerata, in the montane rain forests of the Macaé de Cima area. The genus is apparently poorly represented in semideciduous forests compared to rain forests.

However, there is also an expressive contingent of species that are widely distributed in the neotropics or in two or more domains (Fiaschi \& Pirani 2009). Several studies mention the strong contribution of Myrtaceae to tree component of neotropical forests, particularly Atlantic Forest (Mori et al. 1983; Gentry 1995; Oliveira-Filho \& Fontes 2000; Kamino et al. 2008). According to Mori et al. (1983), under particular environmental conditions, such as in forests with a marked period of flooding or montane forests, where elevation is a major factor determining the local species pool, Myrtaceae species become ecologically dominant. The same author suggests that eastern Brazil, which comprises extensive humid forest formations, represents the diversification nucleus of the family, from which the species would have spread to other habitats.

The most widely distributed genera, Eugenia, Psidium and Myrcia, comprise more than $60 \%$ of the Myrtaceae flora of the upland areas of Minas Gerais, Bahia and Rio de Janeiro. These three genera are also the richest in Brazil, with 356, 214 and 59 species, respectively (Sobral et al. 2010). The groups are unequal in terms of geographic distribution and habitats, the species occurrence ranging from broad to narrow. For example, Eugenia punicifolia, E. florida, Psidium guineense, Myrcia splendens, M. guianensis and M. multiflora occur throughout Brazil and in neighboring countries. In 
Table 4. Results of the generalized linear models used in explaining the floristic gradients summarized by the ordination axes obtained from non-metric multidimensional scaling analysis of the binary occurrence records for 199 species of Myrtaceae in 19 upland areas in central-eastern Brazil.

\begin{tabular}{|c|c|c|c|c|c|c|}
\hline \multirow{5}{*}{ Predictor variable } & \multicolumn{6}{|c|}{ Final model } \\
\hline & \multirow{3}{*}{\multicolumn{3}{|c|}{$\begin{array}{c}\text { NMDS axis } 1 \\
R_{\mathrm{adj}}^{2}=0.694 \\
p<0.01\end{array}$}} & \multirow{3}{*}{\multicolumn{3}{|c|}{$\begin{array}{c}\text { NMDS axis } 2 \\
R_{\text {adj }}^{2}=78.02 \\
p<0.01\end{array}$}} \\
\hline & & & & & & \\
\hline & & & & & & \\
\hline & Coeff. & VIF & $p$ & Coeff. & VIF & $p$ \\
\hline Isothermality & 15.517 & 2.384 & 0.001 & - & - & - \\
\hline Annual precipitation & 0.001 & 2.357 & 0.03 & - & - & - \\
\hline Total precipitation in the driest quarter & -0.069 & 1.024 & 0.001 & - & - & - \\
\hline \multicolumn{7}{|l|}{ Natural logarithm } \\
\hline Isothermality & - & - & - & -3.188 & 2.305 & 0.209 \\
\hline Annual precipitation & - & - & - & 1.837 & 2.292 & 0.018 \\
\hline Total precipitation in the driest quarter & - & - & - & -0.371 & 1.009 & 0.072 \\
\hline
\end{tabular}

NMDS - non-metric multidimensional scaling; $R_{\text {adj }}^{2}$ - adjusted coefficient of determination; Coeff. - coefficient; VIF - variance inflation factor.

stark contrast, Eugenia blanda occurs only in the state of Minas Gerais, and in this study, it was quoted only for the Grão Mogol area; Myrcia vauthieriana is also restricted to Minas Gerais and was found only in the Itacolomi area.

Myrceugenia is an example of a genus with disjunct distribution, occurring in southeastern Brazil and in the Andes. According to Landrum (1981), this type of distribution can be explained by the vicariance hypothesis and suggests the existence of continuous populations across South America during the Tertiary. During the Miocene, the populations were probably divided from east to west as a result of climate changes during that period, such as the end of oceanic transgression, the rise in temperatures and the Andean uplift. Modern-day species of Myrceugenia typically occur at higher elevations with colder climates. In this study, Myrceugenia species were recorded in the areas where there was a combination of higher elevation and higher humidity (Pico das Almas, Catolés, Serra do Cipó, Ouro Branco, Serra do Caraça, Itacolomi, Calçada, Ibitipoca, Macaé de Cima and Itatiaia).

Geographic proximity affected the floristic similarity between some areas, mainly among those within the Quadrilátero Ferrífero region. Therefore, greater geographic distance translates to lower similarity between areas, in terms of the highland Myrtaceae flora. The distribution patterns of birds in the Espinhaço Mountain Range often resembles that of plants, and also show narrow distribution for various taxa (Vasconcelos 2009), with geographic distance and patchy habitats playing important roles in the isolation of species. The geographic isolation of the highest peaks, surrounded by a contrasting matrix of soils and climate probably gives rise to island-like environments, which explains much of the high richness of endemic species in such areas (Giulietti et al. 1997; Martinelli 2007). Geographic isolation is therefore identified as the main reason for the emergence of restricted species, acting as a barrier to dispersal and a restriction to gene flow between populations, which, over evolutionary time, can lead to greater differentiation among genotypes and phenotypes (Lomolino et al. 2010). Martinelli (2007) argued that the high level of species richness and diversity found in tropical highlands is often attributable to the effects of climatic and geological history on biotic evolution, to the various environmental impacts on adaptive mechanisms and to the continuous dispersion of fauna and flora in time. However, little is known about how these factors affect species richness in the highlands of Brazil. Biotic factors (those intrinsic to the biology of the species) seem to play an important role in the distribution of species along environmental gradients. The pollination of Myrtaceae species, for example, is mainly mediated by bees, whereas seed dispersal is more diversified, the agents including birds, monkeys and smaller mammals (Proença \& Gibbs 1994; Gressler et al. 2006). Eugenia mosenii, for example, seems to depend heavily on large frugivorous birds to disperse its seeds (Pizo 2002; Gressler et al. 2006). Studies on seed dispersal of Myrtaceae in Brazil are still scarce but have proved useful in understanding the patterns of geographic distribution of species (Almeida-Neto et al. 2008), underscoring the need for further studies involving the agents of dispersal.

The patterns derived from the two techniques of multivariate analysis (cluster and ordination) were highly congruent and provide strong evidence to support the initial hypotheses. They both showed the influence of spatial proximity as well as that of the domains and their particular geoclimatic characteristics. The main dichotomy among the 19 areas was that between the two areas embedded in a rain forest matrix-Macaé de Cima and Itatiaia-both of which were nearer to the ocean than were the other areas and neither of which had a well-defined dry season, all of the remaining 17 areas having a true dry season, albeit of variable duration (Brade 1956). Oliveira-Filho \& Fontes 
(2000) demonstrated that the floristic distinction between rain and semideciduous forests within the Atlantic Forest Domain is consistent and strongly correlated with the duration of the dry season, although both forest types are quite rich in Myrtaceae species. Two genera with a high rate of occurrence in the Macaé de Cima and Itatiaia areas, Neomitranthes and Plinia, showed a geographic distribution centered in the Atlantic Forest Domain, occurring preferentially in rain forests (Souza 2009).

The second strongest segregation was that of the four areas in the Northern Espinhaço, or Chapada Diamantina Mountain Range (Pai Inácio, Chapadinha, Catolés and Pico das Almas), which is entirely surrounded by the semi-arid Caatinga Domain. Another factor that might contribute to the high floristic dissimilarity of the Northern Espinhaço is its relative isolation from the rest of the mountain range because of a gap of much lower elevations (ca. $500 \mathrm{~m}$ ) between the Chapada Diamantina and the Central Espinhaço in Minas Gerais. This region probably increases the degree of isolation by creating a barrier to the migration of typical highland species (Harley 1995). Apart from these geographical factors, the areas within the Chapada Diamantina also differ from the others to the south in terms of other features, especially their much higher annual minimum temperatures. The flora of the vegetation mosaic, composed mostly of areas of campo rupestre, savanna and forest, is to a certain extent influenced by that of the Caatinga Domain (Harley 1995). The caatinga shrublands and forests are typically composed of a blend of succulents and deciduous woody plants, many of which bear thorns or spines (Andrade-Lima 1981). Although many caatinga species are found at the foot and outer slopes of the Chapada Diamantina, the caatinga vegetation is typically poor in Myrtaceae species (Queiroz et al. 2005). Despite the overwhelming dominance of caatinga vegetation surrounding the Chapada Diamantina, the flora of the highland vegetation mosaic is also strongly influenced by the Cerrado and Atlantic Forest Domains, particularly because of a great number of widely distributed species (Guedes \& Orge 1998), such as Myrcia amazonica, M. guianensis and M. splendens. This probably explains why the cluster analysis grouped the southernmost areas, Catolés and Pico das Almas, together with others of the Central Espinhaço. The southern portion of the Chapada Diamantina, in particular, includes vast areas of cerrado, most of which are over sandy or gravelly soils with low ground water storage capacity (Harley 1995; Zappi 2003).

The areas receiving greater influence from the cerrado flora include not only the Central Espinhaço areas (Grão Mogol, Serra do Rio Preto and Serra do Cabral) but also the Serra da Calçada area, in the Southern Espinhaço, and upland areas that were more distant, such as the Serra da Canastra and Delfinópolis areas, to the west, and the Serra de São José area, to the south. Although the cerrado flora is the most widespread group, it clearly had a major effect on the presence of typical species, such as Eugenia punicifolia and Campomanesia pubescens. According to Ferreira (1980), the cerrado vegetation "presents gradients based on physiognomy, edaphic factors and floristic composition". Ribeiro \& Walter (1998) proposed the so-called "cerrado rupestre" (rocky savanna), reflecting the gradual transition between the cerrado flora, stricto sensu, and that of the campo rupestre. Romero \& Martins (2002) also make this observation when comparing the composition of Melastomataceae in the Serra da Canastra Mountain Range with other localities that have "similar facies", made up of a blend of cerrado and campo rupestre. In addition, our findings support the hypothesis that the Serra da Canastra is a corridor, or stepping stone, between the Espinhaço Mountain Range and the Central Plateau of Brazil, in the state of Goiás, given that most Myrtaceae species of the Serra da Canastra are also typical of areas of cerrado and campo rupestre on the Central Plateau.

The areas receiving greater influence from semideciduous forests within the Atlantic Forest Domain include five areas within the Southern Espinhaço (Serra da Piedade, Serra do Cipó, Caraça, Ouro Branco and Itacolomi) and the Serra do Ibitipoca area, a disjunct portion of the Serra da Mantiqueira. The Itacolomi area is one of the most important geological complexes in Brazil, because of its great mineral wealth and high biodiversity, and has therefore been given the status of "area of special biological importance" (Drummond et al. 2005). Araújo (2008) and Almeida (2008), performing cluster analyses to assess the similarity of Bignoniaceae and Asteraceae floras, respectively, between the Itacolomi area and other areas, found similar groupings, the highest similarities with the Itacolomi area being found for the Serra de Ouro Branco, Caraça and Serra do Cipó areas. The authors attributed this primarily to the geographic proximity between the areas. In the present study, however, we found that the Myrtaceae flora is sensitive to both spatial proximity and geoclimatic variables. The Southern Espinhaço, for example, is characterized by the marked presence of Myrceugenia and Siphoneugena species, which are associated with climates that are more humid and cooler, some species showing disjunct distributions in the Andes (Landrum 1981; McVaugh 1968; Proença 1990). Coincident with this, the Southern Espinhaço areas showed lower temperatures and higher rainfall rates than did the other areas of the Espinhaços.

Studying the tree flora of semideciduous forests in the Espinhaço Mountain Range, Kamino et al. (2008) highlighted the low floristic similarity between the Itacolomi area (referred to as Ouro Preto) and other areas within the Quadrilátero Ferrífero region, which was probably attributable to the higher elevation and lower temperatures of the former. However, Spósito \& Stehmann (2006) found no significant correlations between geographic distance and floristic similarity among eight forest areas within the Quadrilátero Ferrífero region. The authors suggested that variations in temperature, rainfall and elevation, as well as 
the history of disturbance in particular, are the main factors related to the floristic variation. There is therefore sound evidence that geographic distance can only explain the floristic variations in the Southern Espinhaço when associated with changes in climate, lithology and geomorphology. Water availability, for example, is much higher on the eastern side of the Southern Espinhaço because the elevation increases local rainfall by the forced elevation of windward air masses, whereas the western side is much drier due to the rainshadow effect (Santos et al. 2011). This explains why the so-called mares de morros (seas of hills), from the Atlantic coast to the eastern slopes of Espinhaço Mountain Range in central Minas Gerais (Saint-Hilaire 1831; Ab'Saber 2003; Gontijo 2008), was previously covered by Atlantic Forest. The inclusion of the Serra do Ibitipoca, a disjunct portion of the Serra da Mantiqueira, in the Southern Espinhaço cluster probably reflects the transitional character of its vegetation mosaic, which includes species typical of Atlantic Forest, campo rupestre and cerrado (Ferreira \& Magalhães 1977; Salimena 2000).

Statistical models were quite efficient in explaining the variance in Myrtaceae species composition among the 19 upland areas studied, demonstrating the strong sensitivity of this flora to geoclimatic factors. Rather than being concentrated into groups, the floristic pattern showed an ordination across a north to south gradient correlated more strongly with the variation in rainfall distribution and lower extremes of temperature, which reflect the main climatic features of the three domains coinciding with the Espinhaço Mountain Range.

The floristic surveys used in this study highlight the richness and uniqueness of the Myrtaceae flora in the upland areas of Brazil, especially in the Espinhaço Mountain Range. Various studies have focused on the especially rich flora and geological formations of these highlands but have also emphasized that there are still many knowledge gaps on the flora of many localities throughout the Espinhaço (Giulietti \& Pirani 1988; Almeida-Abreu 1995; Harley 1995; Giulietti et al. 1997; Conceição \& Pirani 2005). The floristic differences between the areas become pronounced when we increase the number of study sites (beta diversity increases). Considering that the decisions on conservation basically focus on species richness and the occurrence of endemic restricted range taxa (Drummond et al. 2005), we here emphasize the need for further research efforts in order to improve our knowledge of the regional floras, which are the primary sources of information for the development of conservation activities (Funk \& Richardson 2002).

\section{Acknowledgments}

This study received financial support from the Brazilian Conselho Nacional de Desenvolvimento Científico e Tecnológico (CNPq, National Council for Scientific and Technological Development; Master's scholarship to MOB).
We are grateful to Marcos Sobral for helping us with the checklists; to Danilo Neves, for the valuable discussions and text revision; to Ubirajara Oliveira, for the map; to Pedro Eisenlohr for his contribution to the statistical analyses; and to the authors that conceded their unpublished data.

\section{References}

Ab’Sáber, N.A. 2003. Os domínios de natureza no Brasil: potencialidades paisagísticas. São Paulo, Ateliê Editorial.

Almeida Abreu, P.A. 1995. O Supergrupo Espinhaço da Serra do Espinhaço Meridional (Minas Gerais). O Rifte, a Bacia e o Orógeno. Geonomos 3: 1-18.

Almeida, G.S.S. 2008. Asteraceae Dumont. Dos campos rupestres do Parque Estadual do Itacolomi, Minas Gerais, Brasil. Ph.D. Thesis. Universidade Federal de Viçosa, Viçosa.

Almeida-Neto, M. et al. 2008. Macroecological correlates of vertebratedispersal syndromes along the Atlantic Forest. Global Ecology and Biogeography 17: 503-513.

Alves, R. J. V.; Kolbec, J. 2009. Summit vascular flora of Serra de São José, Minas Gerais, Brazil. Check List 5: 35-73.

Andrade-Lima, D. 1981. The caatingas dominium. Revista Brasileira de Botânica 4: 149-153.

Araújo, R.S. 2008. Bignoniaceae Juss. do Parque Estadual do Itacolomi, Minas Gerais, Brasil: florística, similaridade e distribuição geográfica. Master's Dissertation. Universidade Federal de Viçosa, Viçosa.

Barroso, G,M. \& Peron, M. 1994. Myrtaceae. Pp .261-302. In: Lima M.P.M \& Guedes-Bruni, R.R. Reserva Ecológica de Macaé de Cima, Nova Friburgo, RJ. Aspectos florísticos das espécies vasculares. Rio de Janeiro, Jardim Botânico do Rio de Janeiro.

Barroso, G.M. \& Funch, L.S. 1998. Myrtaceae. In: Guedes, M.L.S. \& Orge, M.D.R. Cheklist das espécies vasculares do Morro do Pai Inácio (Palmeiras) e Serra da Chapadinha (Lençóis) Chapada Diamantina, Bahia, Brasil.

Batalha, M.A. 2011. O cerrado não é um bioma. Biota Neotropica 11: 21-24.

Benites, V. M. 2001. Caracterização de solos e de substâncias húmicas em áreas de vegetação rupestre de altitude. Ph.D. Thesis. Universidade Federal de Viçosa. Viçosa, MG. Brasil.

Brade, A.C. 1956. A flora do Parque Nacional do Itatiaia. Boletim do Parque Nacional do Itatiaia 5: 7-85.

Clarke, H.D. \& Funk, V.A. 2005. Using checklists and collections data to investigate plant diversity: II. An analysis of five florulas from northeastern South America. Proceedings Academy of Nature Science 154: 29-37.

Conceição, A.A. \& Pirani, J.R. 2005. Delimitação de hábitats em campos rupestres na Chapada Diamantina: substratos, composição florística e aspectos estruturais. Boletim de Botânica da Universidade de São Paulo 23: 85-111.

Diniz-Filho, J.A.F. et al. 2003. Spatial autocorrelation and red herrings in geographical ecology. Global Ecology and Biogeography 12: 53-64.

Drummond, G.M. et al. 2005. Biodiversidade de Minas Gerais, um atlas para sua conservação. Fundação Biodiversitas, Belo Horizonte, MG, Brasil.

Ferreira, M.B. \& Magalhães, G.M. 1977. Contribuição para o conhecimento da vegetação da Serra do Espinhaço em Minas Gerais (Serras do Grão Mogol e da Ibitipoca). Anais do XXVI Congresso Nacional de Botânica RJ, Brasil.

Ferreira, M.B. 1980. Frutos nativos do cerrado em Minas Gerais. Informe Agropecuário 61: 19-23.

Fiaschi, P. \& Pirani, J.R. 2009. Review of plant biogeographic studies in Brazil. Journal of Systematic Evolution 47: 477-496.

Fortin, M.J. \& Dale, M. 2005. Spatial analysis: a guide for ecologists Cambridge, Cambridge University Press.

Funk, V.A. \& Richardson, K.S. 2002. Systematic data in biodiversity studies: use it or lose it. Systematic Biology 51: 303-316. 
Funk, V.A. 2006. Floras: a model for biodiversity studies or a thing of the past? Taxon 55: 581-588.

Gauch Jr., H.G. 1982. Multivariate Analysis in Community Structure. Cambridge, Cambridge University Press.

Gentry, A.H. 1982. Neotropical floristic diversity: phytogeographical connections between Central and South America, Pleistocene climatic fluctuations, or an accident of the Andean orogeny? Annals of Missouri Botanical Garden 69: 557-593.

Gentry, A.H. 1995. Diversity and floristic composition of Neotropical dry forests. Seasonally dry tropical forests. Pp. 146-194. Cambridge, Cambridge University Press.

Giulietti, A.M. \& Pirani, J.R. 1988. Patterns of geographic distribution of some plant species from Espinhaço Range, Minas Gerais and Bahia, Brazil. Pp. 39-69. In: Vanzolini, P. \& Heyer, W.R. (Eds.), Proceedings of a workshop on neotropical distribution patterns. Academia Brasileira de Ciências, Rio de Janeiro.

Giulietti, A.M. et al. 1997. Espinhaço range region. Pp. 397-404. In: Davis SD et al. (Eds.), Centres of Plant Diversity, vol. 3. The Americas. WWF-IUCN, Washington.

Gontijo, B.M . 2008. Uma geografia para a Cadeia do Espinhaço. Megadiversidade 4: 7-14.

Govaerts, R. et al. 2007. World checklist of selected families: Myrtaceae. http://www.kew.org/wcsp/. (Accessed 16 Mai 2011).

Gressler, E.; Pizo, M.A.; Morellato, L.P.C. 2006. Polinização e dispersão de sementes em Myrtaceae do Brasil. Revista Brasileira de Botânica 29: 509-530.

Guedes, M.L.S. \& Orge, M.D.R. 1998. Cheklist das espécies vasculares do Morro do Pai Inácio (Palmeiras) e Serra da Chapadinha (Lençóis) Chapada Diamantina, BA, Brasil.

Hammer, Ø. et al. 2001. PAST: Paleontological statistics software package for education and data analysis. Paleontologia Eletronica 4: 1-9.

Harley, R.M. 1995. Introduction. In: Stannard BL, Harvey, YB, Harley RM (Eds.) Flora of the Pico das Almas, Chapada Diamantina - Bahia. Royal Botanic Garden, Kew.

Hatschbach, G. et al. 2006. Aspectos fisionômicos da vegetação da Serra do Cabral, Minas Gerais-Brasil. Boletim do Museu Botânico Municipal, Curitiba 67: 1-33.

Henderson, P.A. \& Seaby, R.M.H. 2007. Community Analysis Package 4.0. Lymington, Pisces Conservation Ltd.

Hijmans, R.J. et al. 2005. Very high resolution interpolated climate surfaces for global land areas. International Journal of Climatology 25: $1965-1978$.

Hill, M.O .1973. Reciprocal averaging: an eigenvector method of ordination. Journal of Ecology 61: 237-249.

Hill, M.O. \& Gauch, H.G .1980. Detrended correspondence analysis: an improved ordination technique. Vegetatio 42: 47-58.

Kamino, L.H.Y.; Stehmann, J.R.; Oliveira-Filho, A.T. 2008 Relações florísticas entre as fitofisionomias florestais da Cadeia do Espinhaço, Brasil. Megadiversidade 4: 38-77.

Kawasaki, M.L. 1989. Flora da Serra do Cipó, Minas Gerais: Myrtaceae. Boletim de Botânica da Universidade São Paulo 11: 121-170

Kawasaki, M.L. 2004. Flora de Grão-Mogol, Minas Gerais: Myrtaceae. Boletim de Botânica da Universidade de São Paulo 22: 323-337.

Kent, M.; Coker, P. 1992. Vegetation description and analysis: a practical approach. London, Belhaven.

Landrum, L.R. 1981. A Monograph of the Genus Myrceugenia (Myrtaceae). Flora Neotropica 29: 1-137.

Landrum, L.R. 1986. Campomanesia, Pimenta, Blepharocalix, Legrandia, Acca, Myrrhinium and Luma. Flora Neotropica 45: 1-178.

Legendre, P. \& Fortin, M.J. 1989. Spatial pattern and ecological analysis. Vegetation 80: 107-138.

Lomolino, M.V.; Riddle, B.R.; Whittaker, R.J. \& Brown, J.H. 2010. Biogeography, 4. ed. Sunderland, Sinauer Associates.

Martinelli, G. 2007. Mountain biodiversity in Brazil. Revista Brasileira de Botânica 4: 587-597.

McCune, B. \& Grace, J.B. 2002. Analysis of ecological communities. Gleneden Beach, MjM Software Design,.

McCune, B. \& Mefford MJ. 2006. PC-ORD, Multivariate analysis of ecological data, Version 5. MjM Software Design, Gleneden Beach, Oregon, USA.
McVaugh, R. 1968. The Genera of American Myrtaceae - An Interim Report. Taxon 17: 354-418.

Morais, P.O. \& Lombardi, J.A. 2006. A Família Myrtaceae na Reserva Particular do Patrimônio Natural da Serra do Caraça, Catas Altas, Minas Gerais, Brasil. Lundiana 7: 3-32.

Mori, S.A. et al. 1983. Ecological importance of Myrtaceae in an eastern Brazilian wet forest. Biotropica 15: 68-70.

Mueller-Dombois, D. \& Ellenberg, H. 1974. Aims and methods of vegetation ecology. New York, Wiley \& Sons.

Nic Lughadha, E. 1995. Myrtaceae. In: Stannard, B.L. (Ed.). Flora of the Pico das Almas. Pp. 492-517. Kew, Royal Botanic Gardens.

Oliveira-Filho, A.T. 2009. Classificação das fitofisionomias da América do Sul cisandina tropical e subtropical: proposta de um novo sistema - prático e flexível - ou uma injeção a mais de caos? Rodriguésia 60: $237-258$

Oliveira-Filho, A.T. \& Fontes, M.A.L. 2000. Patterns of floristic differentiation among Atlantic Forests in Southeastern Brazil and the influence of climate. Biotropica 32: 793-810.

Pizo, M.A. 2002. The seed dispersers and fruit syndromes of Myrtaceae in the Brazilian Atlantic forest. Pp. 129-143. In: Levey, D.J.; W.R. Silva \& M. Galetti (Eds.) Seed dispersal and frugivory: ecology, evolution and conservation. Wallingford, Oxfordshire, CABI Publishing.

Prance, G.T. 1982. A review of the phytogeographic evidences for Pleistocene climate changes in the Neotropics. Annals of Missouri Botanical Garden 69: 594-624.

Proença, C.E.B. 1990. A revision of Siphoneugena (Myrtaceae). Edinburg Journal of Botany 47: 239-271.

Proença, C. \& Gibbs, P.E. 1994. Reproductive Biology of Eight Sympatric Myrtaceae from Central Brazil. New Phytologist 126: 343-354.

Proença, C.E.B et al. 2006. Algrizea (Myrteae, Myrtaceae) a new genus from the highlands of Brazil. Systematic Botany 31: 320-326.

Queiroz, L.P. et al. 2005. Caatinga. Pp. 95-120. In: Juncá, F.A.; Funch, L.S.; Rocha, W. (Orgs.) Biodiversidade e conservação da Chapada Diamantina. Brasília, Ministério do Meio Ambiente.

Rangel, T.F.; Diniz-Filho, J.A.F.; Bini, L.M. 2010. SAM: A comprehensive application for Spatial Analysis in Macroecology. Ecography 33: 1-5.

Ribeiro, J.F.; Walter, B.M. 2008. As principais fitofisionomias do bioma Cerrado. Pp. 151-212. In: Sano, S.M.; Almeida, S.P.; Ribeiro, J.F. (Eds.). Cerrado: Ecologia e Flora. Brasília, Embrapa Cerrados.

Romero, R. \& Martins, A. 2002. Melastomataceae do Parque Nacional da Serra da Canastra, Minas Gerias, Brasil. Revista Brasileira de Botânica 25: 19-24.

Safford, H.D. 1999. Brazilian Páramos I. An introduction to the physical environment and vegetation of the campos de altitude. Journal of Biogeography 26: 693-712.

Safford, H.D. 2007. Brazilian Páramos IV. Phytogeography of the campos de altitude. Journal of Biogeography 34: 1701-1722.

Saint-Hilaire, A de. 1831. Tableau de la Végetation Primitive de la Province de Minas Gerais. Thuan, Imprimirie Ve.

Salimena, F.R.G. 2000. Revisão taxonômica de Lippia L. sect. Rhodolippia Schauer (Verbenaceae). Ph.D. Thesis. Universidade de São Paulo.

Sano, S.M.; Almeida, S.P.; Ribeiro, J.F. 2008. Cerrado: ecologia e flora. Brasília, Embrapa Cerrados.

Santos, M.F.; Serafim, H.; Sano, P.T. 2011. Fisionomia e composição da vegetação florestal na Serra do Cipó, MG, Brasil. Acta Botanica Brasilica 25: 793-814

Semir, J. 1991. Revisão taxonômica de Lychnophora Mart. (Vernoniae: Compositae). Ph.D. Thesis. Universidade Estadual de Campinas, São Paulo.

Sobral, M. et al. 2010. Myrtaceae. In: Forzza RC et al. Catálogo de Plantas e Fungos do Brasil. Rio de Janeiro, Intituto de Pesquisas do Jardim Botânico do Rio de Janeiro.

Sokal, R.R. \& Rohlf, F.J. 1995. Domaintry. San Francisco, W.H. Freeman.

Souza, M.C. 2009. Estudos taxônomicos em Myrtaceae no Brasil: Revisão de Neomitranthes Kausel ex D.Legrand e contribuição ao conhecimento da diversidade e conservação de Plinia L. (Myrtaceae Juss.) no Dominío Atlântico. Ph.D. Thesis. Jardim Botânico do Rio de Janeiro. Rio de Janeiro, Rio de Janeiro. 
Spósito, T.C. \& Stehmann, J.R. 2006. Heterogeneidade florística e estrutural de remanescentes florestais da Área de Proteção Ambiental ao Sul da Região Metropolitana de Belo Horizonte (APA Sul-RMBH). Acta Botanica Brasilica 20: 347-362.

Stehmann, J.R. et al. 2009. Plantas da Floresta Atlântica. Rio de Janeiro, Instituto de Pesquisa do Jardim Botânico do Rio de Janeiro.

Thiers, B. 2010. Index Herbariorum: A global directory of public herbaria and associated staff. New York Botanical Garden's Virtual Herbarium. http://sweetgum.nybg.org/ih/. (Accessed 16 Mai 2011).

Valentin, J.L. 2000. Ecologia numérica - uma introdução à análise multivariada de dados ecológicos. Rio de Janeiro, Editora Interciência.

Vasconcelos, M.F. 2009. Avifauna dos campos rupestres e dos campos de altitude do leste do Brasil: levantamento, padrões de distribuição geográfica, endemismo e conservação. Ph.D. Thesis. Universidade Federal de Minas Gerais, Belo Horizonte.

Viana, P.L. \& Lombardi, J.A. 2007. Florística e caracterização dos campos rupestres sobre canga na Serra da Calçada, Minas Gerais, Brasil. Rodriguésia 58: 159-177.

Webster, G.L. 1995. The panorama of Neotropical cloud forests. Pp. 53 77. In: Churchill, S.P. Balslev, H. Forero, E. and Luteyn, J.L. Biodiversity and conservation of Neotropical montane forests. New York, The New York Botanical Garden.

Zappi, D.C. et al. 2003. Lista das plantas vasculares de Catolés, Chapada Diamantina, Bahia, Brasil. Boletim de Botânica da Universidade de São Paulo 21: 345-398.

Zar, J.H. 2009. Biostatistical analysis. 5th ed. New Jersey, Prentice-Hall. 